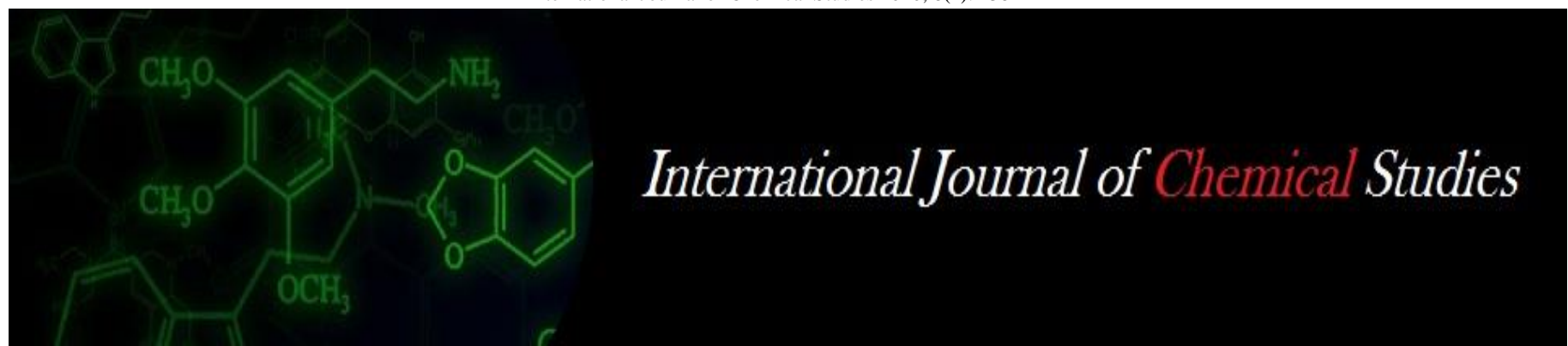

P-ISSN: 2349-8528

E-ISSN: 2321-4902

IJCS 2020; 8(1): 238-241

(C) 2020 IJCS

Received: 10-11-2019

Accepted: 12-12-2019

Dr. GP Banjara

Department of Agronomy, Indira Gandhi Krishi

Vishwavidhyalaya, Raipur, Chhattisgarh, India

Sanjay Kumar Majgahe Department of Agronomy, Indira Gandhi Krishi Vishwavidhyalaya, Raipur, Chhattisgarh, India

Corresponding Author: Dr. GP Banjara

Department of Agronomy, Indira Gandhi Krishi

Vishwavidhyalaya, Raipur, Chhattisgarh, India

\section{Impact of different broad spectrum herbicides on seed and stover yields of chickpea crop (Cicer arietinum $\mathbf{L}$.)}

\author{
Dr. GP Banjara and Sanjay Kumar Majgahe
}

\begin{abstract}
The present investigation "Impact of different broad spectrum herbicides on seed and stover yields of Chickpea Crop (Cicer arietinum L.)" was carried out during Rabi season in 2015-16 and 2016-17 at Instructional Cum Research Farm of IGKV, Raipur (Chhattisgarh). The soil of experimental field was clayey (Vertisols) in texture, locally known as "Kanhar" which was low, medium and high in available $\mathrm{N}, \mathrm{P}_{2} \mathrm{O}_{5}$ and $\mathrm{K}_{2} \mathrm{O}$, respectively. The experiment was laid out in Randomized block Design with three replications. The experiment conducted with Chickpea (Cicer arietinum L.) variety 'Vaibhav' was grown as test crop consists of eleven different herbicides treatment. It was found non significantly difference between plant population at 20 DAS and significance difference between at harvest stage during both the years and on mean basis. The maximum plant population at harvest was recorded under treatment weed free hand weeding at 20 and 40 DAS and minimum was recorded under weed check. Seed yield, stover yield and harvest index found significantly different between all the treatments. Treatment weed free (hand weeding at 20 and 40 DAS) recorded maximum seed yield $(1806.27 \mathrm{~kg} / \mathrm{ha}$ and $1994.40 \mathrm{~kg} / \mathrm{ha}$ ) and minimum (440.67 and 467.07) was in weedy check. Highest stover yield (2985.47 and 3124.4) was obtained under Pendimethalin 30 EC @ $1.0 \mathrm{~kg} \mathrm{ha}^{-1} \mathrm{PE}+$ one hand weeding at 30 DAS) while lowest under weedy check during both the years and on mean basis. Higher harvest index (39.95 and 40.66) recorded under weedy (hand weeding at 20 and 40 DAS) and minimum (18.60 and 18.66) under weedy check.
\end{abstract}

Keywords: Chickpea, plant population, seed and stover yield, harvest index

\section{Introduction}

Chickpea is the second most important pulse crop after pigeon pea in the word for human diet and other use. Chickpea seed has carbohydrate (38-59\%), fiber (3\%), oil (4.8 to 5.5\%), ash (3\%), Calcium $(0.2 \%)$ and phosphorus $(0.3 \%)$. Digestibility of protein varies from $76-78 \%$ and its carbohydrate from 57-60\% (Hulse, 1991, Huisman and van der poel, 1994). Since 1990 , a rise in the productivity of chickpea in India has been observed from $614 \mathrm{~kg}$ per hectare to $735 \mathrm{~kg}$ per hectare. The yield of chickpea was highest in Andhra Pradesh $(1615 \mathrm{~kg}$. $/ \mathrm{ha})$, followed by Bihar (1000 kg./ha), West Bengal (1000 kg./ ha.) M.P. (926 kg./ha). U.P. (892 kg. /ha) and Gujrat $(892 \mathrm{~kg}$. /ha.). The yield of other states is below the country average (808 $\mathrm{kg} / \mathrm{ha}$.). In Chhattisgarh, chickpea is grown over an area of 366.10 thousand ha and average productivity of $1100 \mathrm{~kg} / \mathrm{ha}$ (Anonymous, 2016-17). In chickpea production, one of the major constraints is weed infestation. Weeds compete with crop plants for space, water and nutrients and hence, it negatively affected plant population and yield. Chickpea is poor competitor to weeds because of slow growth rate and limited leaf development at early stage of crop growth and establishment, if weed management is neglected under these conditions, resulting in yield loss of 40 to $87 \%$ (Ratnam et al., 2011) ${ }^{[13]}$. Thus, weeds are one of the major constraints to obtain high grain yield of improved crop cultivars if they are not controlled timely and properly. Yield losses due to weed competition vary considerably depending on the level of weed infestation and weed species prevailing. The important weeds found in weed of chickpea includes Chenopodium album, Medicago denticulata, Echinocloa colona, Parthenium hysterophorus, Cynodon dactylon, Hand weeding and mechanical weed control methods traditionally followed in the developing countries are becoming expensive due to increased labor wages. Because of the sensitivity of chickpea to herbicides, most effective are the preemergence herbicides, and choices for post-emergence herbicides are limited. The preemergence herbicides are effective in controlling weeds at early stage of seedling growth, but 
weeds germinating after crop emergence become dominant in the field and cause substantial yield loses. Weed management through herbicides is not only economical but also facilitates zero tillage or minimum tillage methods, which help in practicing conservation agriculture. Pre-emergence treatments are applied after seeding but before the crop emerges. Selective herbicides weeds are killed with little damage to crop plants due to differential tolerance of the crop and weed to the herbicides. Chickpea is known to be sensitive to many herbicides and, therefore, choices for using post-emergence herbicides for weed control are limited. Within the limited available herbicide options, the main chickpea herbicide Pendimethalin are registered only for pre-emergent use. Up to $1 \mathrm{~kg} \mathrm{ha}^{-1}$ Pendimethalin is registered for pre-emergent use on chickpeas.

\section{Material and Methods}

A field experiment was carried out at Instructional Cum Research Farm of IGKV, Raipur (Chattisgarh), during Rabi season in 2015-16 and 2016-17. Different weed management practices were done as per the treatments in the experiment. Herbicide pendimethalin 30 EC @ $1000 \mathrm{~g} \mathrm{ha}^{-1}$ was applied as preemergence at 2 DAS in treatment T1, T2, T3, T6, T7 and T8, respectively. Pendimethalin (extra) 30 EC @ $1000 \mathrm{~g} \mathrm{ha}^{-1}$, Pendimethalin (extra) $38.7 \%$ CS @ $1000 \mathrm{~g} \mathrm{ha} \mathrm{ha}^{-1}$, Sulfenotrazon 39.6 EC @ 50g ha-1, Fenoxaprop-p-ethyl 9.3 EC @ 60 $\mathrm{g} \mathrm{ha}^{-1}$ and combination of Pendimethalin $30 \mathrm{EC}+$ Imazethapyr $2 \%$ (Ready mix) @ $1.0 \quad \mathrm{~kg} \mathrm{ha}^{-1}$ and Pendimethalin 38.7 CS @ $1.0 \mathrm{~kg} \mathrm{ha}^{-1}+$ Imazethapyr 2\% (tank mix)@1.0 kg ha ${ }^{-1}$ were also applied as pre-emergence in treatment T1, T2, T3, T4,T6, T7 and T8, respectively, at 2 DAS. Fenoxaprop-p-ethyl 9.3EC @ 60g ha-1 was applied as post emergence at $25 \mathrm{DAS}$ in T5. Herbicide dissolved thoroughly in water at the rate of 500 liter as $\mathrm{ha}^{-1}$ as carrier and sprayed in their respective plots. The calculated above mentioned quantity of herbicide, as per treatment, was mixed in 1.5 liter of water and sprayed over the gross plot by knapsack sprayer using flat fan nozzle as blind application. Water at the rate of 500 liter ha $\mathrm{ha}^{-1}$ as carrier and sprayed with knapsack Sprayer. Weed management practices were adopted as per treatments. Two manual hand weeding were done at 30 days and other treatment at 20 and 40 days after sowing. One treatment for weedy check.

\section{Results and Discussion Plant population (No. $/ \mathrm{m}^{2}$ )}

The data based on two years and on mean basis presented in Table 1 revealed that plant population at 20 DAS was found non-significant among all weed management treatments. However, at harvest the maximum plant population was recorded under treatment weed free hand weeding at 20 and 40 DAS and it was at par with treatment Pendimethalin 30 EC + Imazethapyr $2 \%$ SL (Ready mix) @ 1.0kg ha ${ }^{-1} \mathrm{PE}+$ one hoeing at 30 DAS significantly superior over others. It might be due to better germination and less mortality of plant. Minimum plant population at harvest was recorded under weed check.

Table 1: Plant population (No. $/ \mathrm{m}^{2}$ ) of chickpea as influenced by different weed control measures

\begin{tabular}{|c|c|c|c|c|c|c|}
\hline \multirow{2}{*}{ Treatment } & \multicolumn{5}{|c|}{ Plant population $\left(\mathbf{N o .} / \mathbf{m}^{\mathbf{2}}\right)$} \\
\cline { 2 - 7 } & \multicolumn{3}{|c|}{ At 20 DAS } & \multicolumn{3}{c|}{ At harvest } \\
\cline { 2 - 7 } & $\mathbf{2 0 1 5 - 1 6}$ & $\mathbf{2 0 1 6 - 1 7}$ & Mean & $\mathbf{2 0 1 5 - 1 6}$ & $\mathbf{2 0 1 6 - 1 7}$ & Mean \\
\hline Pendi EC+HW & 29.87 & 30.00 & 29.93 & 27.13 & 27.47 & 27.20 \\
\hline Pendi CS & 29.27 & 29.67 & 29.47 & 26.67 & 27.27 & 26.73 \\
\hline PendiCS+Hoe & 30.67 & 31.07 & 30.87 & 27.80 & 27.67 & 27.63 \\
\hline Sulfe+Hoe & 29.33 & 29.53 & 29.43 & 26.27 & 26.60 & 26.33 \\
\hline Fenox POE & 28.67 & 29.13 & 28.90 & 26.13 & 26.20 & 26.27 \\
\hline Velor 32 & 29.40 & 29.80 & 29.60 & 27.13 & 27.47 & 27.20 \\
\hline Velor 32+ Hoe & 30.73 & 31.87 & 31.30 & 29.00 & 29.67 & 29.20 \\
\hline Pendi+Imaze & 29.13 & 29.53 & 29.33 & 26.73 & 27.07 & 26.80 \\
\hline HW & 28.73 & 29.13 & 28.93 & 27.13 & 27.47 & 27.20 \\
\hline WF & 32.73 & 32.27 & 32.50 & 31.07 & 31.13 & 31.33 \\
\hline WC & 28.47 & 28.87 & 28.67 & 25.53 & 25.93 & 25.37 \\
\hline CD at 5\% & NS & NS & NS & 2.74 & 2.82 & 2.72 \\
\hline
\end{tabular}

\section{Seed and stover yields $(\mathrm{kg} / \mathrm{ha})$}

Data based on two years and on the mean basis revealed that seed yield and stover yield significantly affected by all weed management practices on chickpea are presented in Table 2 Among weed management practices, Treatment weed free (hand weeding at 20 and 40 DAS) recorded significantly higher seed yield (1806.27 kg/ha and $1994.40 \mathrm{~kg} / \mathrm{ha})$ during both the years and on mean basis which was at par with the treatment of Pendimethalin $30 \mathrm{EC}+$ Imazethapyr $2 \%$ (Ready mix)@1.0 kg ha-1 PE + one hoeing at 30 DAS and Pendimethalin 38.7 CS @ 1.0 kg ha-1 PE + one hoeing at 30 DAS. The minimum seed yield was recorded under weedy check. Similar results also reported by Butter et al. (2008), Chaudhary et al. (2011) ${ }^{[4]}$, Hassan and Khan (2007), Kumar et al. (2011) ${ }^{[7]}$, Ratnam et al. (2011) ${ }^{[13]}$. Sharma (2009) ${ }^{[14]}$, Singh et al. (2008) [16], Higher seed yield under above treatments might be due to the proper utilization of moisture, nutrients light and space by the chickpea crop in the absence of weed competition.

The data based on two years and on mean basis were found that higher stover yield (2985.47 and 3124.40) was obtained under Pendimethalin 30 EC @ $1.0 \mathrm{~kg} \mathrm{ha}^{-1} \mathrm{PE}$ +one hand weeding at $30 \mathrm{DAS}$ ) which was at par with the treatments Sulfenotrazon $39.6 \mathrm{EC} @ 50 \mathrm{~g} \mathrm{ha}^{-1} \mathrm{PE}+$ one hoeing at 30 DAS, Pendimethalin $38.7 \mathrm{CS} @ 1.0 \mathrm{~kg} \mathrm{ha}^{-1} \mathrm{PE}+$ one hoeing at 30 DAS, Pendimethalin 30 EC + Imazethapyr $2 \%$ SL (Ready mix ) @ $1.0 \mathrm{~kg} \mathrm{ha}^{-1} \mathrm{PE}$, Pendimethalin $30 \mathrm{EC}+$ Imazethapyr 2 $\%$ SL (Ready mix) @ 1.0kg ha ${ }^{-1} \mathrm{PE}+$ one hoeing at $30 \mathrm{DAS}$, Hand weeding at 30 DAS, and Weed free (hand weeding at 20 and 40 DAS. The lowest stover yield was recorded under weedy check. The higher stover yield in above treatments might be due to lesser weeds during early crop growth period, higher yield attributes and pod yield which leads to higher stover yield. While, in control plot reverse trend was observed 
and therefore, the lowest stover yield was noted under this treatment. Similar findings reported by Patel et al. $(2006)^{[10]}$.

\section{Harvest Index}

The data based on two years and on mean basis harvest index (HI) presented in Table 2 was found significantly influenced by various weed management practices. Higher harvest index (39.95 and 40.66) recorded under weedy (hand weeding at 20 and 40 DAS) and it was at par with the treatment of Pendimethalin 30 EC + Imazethapyr 2\% SL (Ready mix)
@ $1.0 \mathrm{~kg} \mathrm{ha}^{-1} \mathrm{PE}$ +one hoeing at 30 . The minimum harvest index (18.60 and 18.66) was obtained under weedy check due to low seed yield and more crop-weed competition. Maximum harvest index under these treatments might be due to proper reproductive growth due to timely translocation of photosynthesis from source to sink thus increase the seed production ratio in total produce. Similar findings reported by Kaushik et al. (2014).

Table 2: Seed and stover yield $(\mathrm{kg} / \mathrm{ha})$ and harvest index $(\%)$ of chickpea as influenced by different weed control measures

\begin{tabular}{|c|c|c|c|c|c|c|c|c|c|}
\hline \multirow{2}{*}{ Traetment } & \multicolumn{3}{|c|}{ Seed yield ( kg/ha) } & \multicolumn{3}{c|}{ Stover yield ( kg/ha) } & \multicolumn{3}{c|}{ Harvest index (\%) } \\
\cline { 2 - 11 } & $\mathbf{2 0 1 5 - 1 6}$ & $\mathbf{2 0 1 6 - 1 7}$ & Mean & $\mathbf{2 0 1 5 - 1 6}$ & $\mathbf{2 0 1 6 - 1 7}$ & Mean & $\mathbf{2 0 1 5 - 1 6}$ & $\mathbf{2 0 1 6 - 1 7}$ & Mean \\
\hline Pendi EC+HW & 1602.80 & 1741.77 & 1672.28 & 2985.47 & 3124.4 & 3054.95 & 34.94 & 35.80 & 35.37 \\
\hline Pendi CS & 1097.27 & 1208.53 & 1152.90 & 2547.00 & 2666.8 & 2606.90 & 34.92 & 31.21 & 33.07 \\
\hline PendiCS+Hoe & 1674.73 & 1816.63 & 1745.68 & 2900.40 & 3042.3 & 2971.35 & 35.10 & 37.38 & 36.24 \\
\hline Sulfe+Hoe & 1486.47 & 1628.13 & 1557.30 & 2960.53 & 3102.2 & 3031.37 & 33.40 & 34.41 & 33.91 \\
\hline Fenox POE & 1034.53 & 1154.53 & 1094.53 & 2560.43 & 2680.4 & 2620.43 & 28.85 & 30.18 & 29.52 \\
\hline Velor 32 & 1310.60 & 1452.27 & 1381.43 & 2761.80 & 2903.5 & 2832.63 & 32.16 & 33.33 & 32.75 \\
\hline Velor 32+ Hoe & 1750.60 & 1958.53 & 1854.57 & 2733.80 & 2927.6 & 2830.68 & 39.02 & 40.06 & 39.54 \\
\hline Pendi+Imaze & 1183.93 & 1324.60 & 1254.27 & 2644.53 & 2785.2 & 2714.87 & 30.91 & 32.23 & 31.57 \\
\hline HW & 1350.93 & 1490.07 & 1420.50 & 2723.53 & 2862.7 & 2793.10 & 33.13 & 34.21 & 33.67 \\
\hline WF & 1806.27 & 1994.40 & 1900.33 & 2710.30 & 2905.4 & 2807.83 & 39.95 & 40.66 & 40.30 \\
\hline WC & 440.67 & 467.07 & 453.87 & 1925.27 & 2047.7 & 1986.47 & 18.60 & 18.66 & 18.63 \\
\hline CD at 5\% & 168.73 & 180.83 & 174.33 & 279.96 & 311.83 & 290.85 & 2.34 & 1.58 & 1.53 \\
\hline
\end{tabular}

\section{Conclusion}

The relevant study based on both the years and mean basis it concluded that plant population recorded at 20 DAS were non-significantly differs under various weed management treatments, while at harvest significantly highest plant population was found under weed free (hand weeding at 20 and 40 DAS) and minimum in weedy check

The data on seed yield, stover yield and harvest index during the years and on the mean basis showed significacnt difference under all the treatments. Maximum seed yield and harvest index were recorded under weedy (hand weeding at 20 and 40 DAS) and minimum uder weedy check. While stover yield maximum in treatment Pendimethalin 30 EC @ $1.0 \mathrm{~kg} \mathrm{ha}^{-1} \mathrm{PE}$ +one hand weeding at $30 \mathrm{DAS}$ ) and minimum in weedy check.

\section{Reference}

1. Anonymous. Directorate of Economics and Statistics. Department of Agriculture and Cooperation. Ministry of Agriculture, Government of India, 2014.

2. Buttar GS, Aggarwal N, Singh S. Efficacy of different herbicides in chickpea (Cicer arietinum L.) under irrigated conditions of Punjab. Indian Journal of Weed Science. 2008; 40(3\&4):169-171.

3. Chandakar S, Sharma A, Thakur DK. Effect of chickpea (Cicer arietinum L.) varieties and weed management practices on quality parameters, nutrient content and uptake by crop and weed. J Progressive Agri. 2015; 6:2931.

4. Chaudhary SU, Iqbal J, Hussain M, Wajid A. Economical weed control in lentil crop. The Journal of Animal \& Plant Sciences. 2011; 21(4):734-737.

5. FAO. Food and Agriculture Organization of the United Nations. Faostat.fao.org. 2017

6. Goud VV, Murade NB, Kharke MS, Patil AN. Efficacy of Imazethapyr and Quizalofop-ethyl herbicides on growth and yield of chickpea. The Bioscan. 2013; $8: 1015-1018$.
7. Kumar S, Singh R, Kumar A. Performance of chickpea (Cicer arietinum L.) under varied seed rate, geometry and weed management conditions. Progressive Agriculture. 2011; 11(1):133-137.

8. Khan A, Khan IA, Khan R, Khan I, Hussain Z, Humayun $\mathrm{R}$ et al. Important chickpea weeds of new developmental farm, khyber pakhtunkhwa agricultural university Peshawar, Pakistan. Pakistan J Weed Sci. Res. 2011; 17(3):271-276.

9. Kumar, Shiv. Weed management studies in summer mung. Ph.D. Dissertation, Haryana Agricultural University, Hissar, HARYANA (INDIA), 1985.

10. Patel BD, Patel VJ, Surya MMI. Effect of FYM, molybdenum and weed management practices on weeds, yield attributes and yield of chickpea. Indian Journal of Weed Science. 2006; 38(3\&4):244-246

11. Patel BD, Patel VJ, Patel JB, Patel RB. Effect of fertilizers and weed Int. J Curr. Microbiol. App. Sci. 2006-2017, 6(3).

12. Poonia TC, Pithia MS. Pre-and post-emergence herbicides for weed management in chickpea. Indian Journal of Weed Science. 2013; 45(3):223-225.

13. Ratnam M, Rao AS, Reddy TY. Integrated weed management in chickpea (Cicer arietinum L.). Indian $\mathbf{J}$ Weed Sci. 2011; 43(1\&2):70-72.

14. Sharma OL. Weed management in chickpea under irrigated conditions of Western Rajasthan. Indian Journal of Weed Science. 2009; 41(3\&4):182-184.

15. Singh G, Aggarwal N, Ram H. Efficacy of postemergence herbicide imazethapyr for weed management indifferent mungbean (Vigna radiata L.) cultivars. Indian J Agric. Sci. 2014; 84(4):540-543.

16. Singh S, Walia US, Singh B. Effective control of weeds in chickpea (Cicer arietinum). Indian Journal of Weed Science. 2008; 40(1\&2):51-55.

17. Jat BL, Gupta JK, Meena RL, Sharma RN, Bhati DS. Effect of foliar application of zinc sulphate and thiourea on productivity and economics of chickpea (Cicer 
aritenum). Journal of Progressive Agriculture. 2014; $5(2): 62-65$.

18. Khan HR, Mc Donald GK, Rengel Z. Zn fertilization improves water use efficiency, grain yield and seed $\mathrm{Zn}$ content in chickpea. Plant and Soil. 2003; 249:389-400.

19. Mali GS, Sharma NN, Acharya HK, Gupta SK, Gupta PK. Response of pigeon pea to $\mathrm{S}$ and $\mathrm{Zn}$ fertilization on vertisols in south- eastern plain of Rajasthan. Advances in Arid Legumes Research, 2003, 267-271.

20. Nandan B, Sharma BC, Chand G, Bazgalia K, Kumar R, Banotra M. Agronomic fortification of $\mathrm{Zn}$ and $\mathrm{Fe}$ in chickpea an emerging tool for nutritional security - A Global Perspective. Acta Scientific Nutritional Health. 2018; 2:12-19.

21. Shakya MS, Patel MM, Singh VB. Knowledge level of chickpea growers about chickpea production technology. Indian Research Journal of Extention Education. 8: 6568. \& Forestry. 2008; 57(11):53-66. 